\title{
9 Referencias bibliográficas
}

Abbott, Barbara, Definiteness and familiarity, in: Gundel, Jeanette/Abbott, Barbara (edd.), The Oxford handbook of reference, Oxford, Oxford University Press, 2019, 117-129.

Ackerman, Farrell/Moore, John, Syntagmatic and paradigmatic dimensions of causee encodings, Linguistics and philosophy 22:1 (1999), 1-44.

Aissen, Judith, Differential object marking. Iconicity vs. economy, Natural language \& linguistic theory 21:3 (2003), 435-483.

Alarcos Llorach, Emilio, Gramática de la lengua española, Madrid, Espasa Calpe, 1999.

Alfaraz, Gabriela G., Accusative object marking. A change in progress in Cuban Spanish?, Spanish in context 8:2 (2011), 213-234.

Alfonso Vega, Milagros, Construcciones causativas en el español medieval. Estructura y evolución, México, UNAM/El Colegio de México, 1998.

Alsina, Alex, On the argument structure of causatives, Linguistic inquiry 23:4 (1992), 517-555.

Álvarez Huerta, Olga, Acusativo, in: Baños, José Miguel (ed.), Sintaxis del latín clásico, Madrid, Liceus, 2009, 131-154.

Anderson, Mona K. J., Noun phrase structure, Doctoral thesis, University of Connecticut, 1979.

Asher, Roland E./Kumari, T. C., Malayalam, London/New York, Routledge, 1997.

Balasch, Sonia, Factors determining Spanish differential object marking within its domain of variation, in: Michnowicz, Jim/Dodsworth, Robin (edd.), Selected proceedings of the 5th workshop on Spanish sociolinguistics, Somerville, MA, Cascadilla proceedings project, 2011, 113-124.

Baños, José Miguel, Dativo, in: Baños, José Miguel (ed.), Sintaxis del latín clásico, Madrid, Liceus, 2009, 185-210.

Barraza Carbajal, Georgina, Estructura y evolución de la frase nominal de objeto directo inanimado en español, Medievalia 35 (2003), 155-182 (= 2003a).

Barraza Carbajal, Georgina, Evolución del objeto directo inanimado en español, UNAM, México, 2003 (= 2003b).

Barraza Carbajal, Georgina, Marcación preposicional de objeto directo inanimado, in: Company Company, Concepción/Moreno de Alba, José G. (edd.), Actas del VII congreso internacional de historia de la lengua española. Mérida (Yucatán), 4-8 septiembre de 2006, vol. 1, Madrid, Arco Libros, 2008, 341-352.

Bates, Douglas, et al., Fitting linear mixed-effects models using Ime4, Journal of statistical software 67 (2015), 1-48.

Beavers, John, An aspectual analysis of ditransitive verbs of caused possession in English, Journal of semantics 28:1 (2010), 1-54.

Beavers, John, On affectedness, Natural language \& linguistic theory 29:2 (2011), 335-370.

Bello, Andrés, Gramática de la lengua castellana destinada al uso de los americanos, Santiago de Chile, Imprenta del Progreso, 1847.

Blume, Kerstin, A contrastive analysis of interaction verbs with dative complements, Linguistics 36: 2 (1998), 253-280.

Boas, Taylor C./Christenson, Dino P./Glick, David M., Recruiting large online samples in the United States and India. Facebook, mechanical turk, and qualtrics, Political science research and methods 8:2 (2020), 232-250.

Bosque, Ignacio/Gutiérrez-Rexach, Javier, Fundamentos de sintaxis formal, Madrid, Akal, 2009.

Ә Open Access. (c) 2022 Diego Romero Heredero, published by De Gruyter. (c) BY-NC-ND This work is licensed under the Creative Commons Attribution-NonCommercial-NoDerivatives 4.0 International License.

https://doi.org/10.1515/9783110751734-009 
Bossong, Georg, Historische Sprachwissenschaft und empirische Universalienforschung, Romanistisches Jahrbuch 33 (1982), 17-51.

Bossong, Georg, Empirische Universalienforschung. Differentielle Objektmarkierung in den neuiranischen Sprachen, Tübingen, Narr, 1985.

Bossong, Georg, Differential object marking in Romance and beyond, in: Wanner, Dieter/ Kibbee, Douglas A. (edd.), New analyses in Romance linguistics. Selected papers from the XVIII linguistic symposium on Romance languages 1988, Amsterdam, John Benjamins, 1991, 143-170.

Bruce, Leslie P., The Alamblak language of Papua New Guinea (East Sepik), Canberra, Australian National University, 1984.

Cabrillana Leal, Concepción, Nominativo y vocativo, in: Baños, José Miguel (ed.), Sintaxis del latín clásico, Madrid, Liceus, 2009, 111-130.

Campos, Héctor, Transitividad e intransitividad, in: Bosque, Ignacio/Demonte, Violeta (edd.), Gramática descriptiva de la lengua española, vol. 2: Las construcciones sintácticas fundamentales. Relaciones temporales, aspectuales y modales, Madrid, Espasa Calpe, 1999, 1519-1574.

Cano Aguilar, Rafael, Estructuras sintácticas transitivas en el español actual, Madrid, Gredos, 1981.

Christophersen, Paul, The articles. A study of their theory and use in English, Copenhagen, Munksgaard, 1939.

Company Company, Concepción, Multiple dative-marking grammaticalization. Spanish as a special kind of primary object language, Studies in language 25: 1 (2001), 1-47.

Company Company, Concepción, El avance diacrónico de la marcación prepositiva en objetos directos inanimados, in: Bernabé Pajares, Alberto, et al. (edd.), Presente y futuro de la lingüística en España. La Sociedad de Lingüística, 30 años después. Actas del II congreso de la Sociedad Española de Lingüística, vol. 2, Madrid, Sociedad Española de Lingüística, 2002, 146-154 (= 2002a).

Company Company, Concepción, Grammaticalization and category weakness, in: Wischer, Ilse/Diewald, Gabriele (edd.), New reflections on grammaticalization, Amsterdam/ Philadelphia, John Benjamins, 2002, 201-215 (= 2002b).

Company Company, Concepción, Transitivity and grammaticalization of object. The struggle of direct and indirect object in Spanish, in: Fiorentino, Giuliana (ed.), Romance objects. Transitivity in Romance languages, Berlin/New York, De Gruyter Mouton, 2003, 217-260.

Company Company, Concepción, El objeto indirecto, in: Company Company, Concepción (ed.), Sintaxis histórica de la lengua española. Primera parte: La frase verbal, México, Fondo de Cultura Económica y Universidad Nacional Autónoma de México, 2006, 479-574.

Company Company, Concepción, La preposición a, in: Company Company, Concepción (ed.), Sintaxis histórica de la lengua española. Tercera parte: Adverbios, preposiciones y conjunciones. Relaciones interoracionales, vol. 2, México, Fondo de Cultura Económica y Universidad Nacional Autónoma de México, 2014, 1197-1339.

Comrie, Bernard, Definite and animate direct objects. A natural class, Linguistica silesiana 3 (1979), 13-21.

Comrie, Bernard, Markedness, grammar, people, and the world, in: Eckman, Fred R./Moravcsik, Edith A./Wirth, Jessica R. (edd.), Markedness, Boston, MA, Springer, 1986, 85-106.

Comrie, Bernard, Language universals and linguistic typology. Syntax and morphology, University of Chicago Press, 1989. 
Coseriu, Eugenio, Determinación y entorno. Dos problemas de una lingüística del hablar, Romanistisches Jahrbuch 7 (1955), 29-54.

Croft, William, Syntactic categories and grammatical relations. The cognitive organization of information, Chicago, University of Chicago Press, 1991.

Croft, William, Typology and universals, Cambridge, Cambridge University Press, 2002.

Cruse, David Alan, Some thoughts on agentivity, Journal of linguistics 9:1 (1973), 11-23.

Dahl, Östen, Animacy and egophoricity. Grammar, ontology and phylogeny, Lingua 118:2 (2008), 141-150.

Dahl, Östen/Fraurud, Kari, Animacy in grammar and discourse, in: Gundel, Jeanette K./ Fretheim, Thorstein (edd.), Reference and referent accesibility, Amsterdam, John Benjamins, 1996, 47-64.

Dahl, Östen/Koptjevskaja-Tamm, Maria, Circum-Baltic languages, vol. 2: Grammar and typology, John Benjamins, 2001.

Dalrymple, Mary/Nikolaeva, Irina, Objects and information structure, Cambridge, Cambridge University Press, 2011.

Delbecque, Nicole, Hacia una aclaración cognitiva del acusativo preposicional, Procesamiento del lenguaje natural 14 (1994), 33-45.

Delbecque, Nicole, A construction grammar approach to transitivity in Spanish, in: Davidse, Kristin/Lamiroy, Beatrice (edd.), The nominative and accusative and their counterparts, Amsterdam, John Benjamins, 2002, 81-130.

Delbecque, Nicole/Lamiroy, Beatrice, Towards a typology of the Spanish dative, in: Belle, William van/Langendonck, Willy van (edd.), Casus and grammatical relations across languages. The dative, Amsterdam, John Benjamins, 1996, 73-117.

Demonte, Violeta, Dative alternation in Spanish, Probus 7:1 (1995), 5-30.

Dietrich, Wolf, Romanische Objektmarkierung und das Verhältnis von direktem und indirektem Objekt, in: Dietrich, Wolf/Gauger, Hans-Martin/Geckeler, Horst (edd.), Grammatik und Wortbildung romanischer Sprachen. Beiträge zum deutschen Romanistentag in Siegen 1985, Tübingen, Narr, 1987, 69-79.

Dixon, Robert M. W., Ergativity, Cambridge, Cambridge University Press, 1994.

Dowty, David R., Word meaning and Montague grammar. The semantics of verbs and times in generative semantics and in Montague's PTQ, Dordrecht/Boston/London, Kluwer Academic Publishers, 1979.

Dowty, David R., Thematic proto-roles and argument selection, Language 67:3 (1991), 547-619.

Dryer, Matthew S., Primary objects, secondary objects, and antidative, Language 62:4 (1986), 808-845.

Enghels, Renata, Transitivity of Spanish perception verbs. A gradual category?, Borealis: An international journal of Hispanic linguistics 2:1 (2012), 35-56.

Escandell-Vidal, $M$ - Victoria, Differential object marking and topicality. The case of Balearic Catalan, Studies in language 33:4 (2009), 832-884.

Fábregas, Antonio, Differential object marking in Spanish. State of the art, Borealis: An international journal of Hispanic linguistics 2:2 (2013), 1-80.

Fernández Ramírez, Salvador, Gramática española, vol. 4: El verbo y la oración, Madrid, Arco Libros, 1986.

Fiengo, Robert, Surface structure, Boston, Harvard University Press, 1980.

Filip, Hana, The telicity parameter revisited, in: Young, Robert B. (ed.), Proceedings of the 14th Semantics and Linguistic Theory Conference, Ithaca, New York, CLC Publications, 2004, 92-109. 
Fillmore, Charles J., Toward a modern theory of case, Washington D.C., ERIC, 1966.

Fillmore, Charles J., The case for case, in: Bach, Emmon/Harms, Robert T. (edd.), Universals in linguistic theory, vol. 2, London, Holt, Rinehart \& Winston, 1968, 1-90.

Folgar, Carlos, Diacronía de los objetos directo e indirecto (del latín al castellano medieval), Santiago de Compostela, Universidad de Santiago de Compostela, 1993.

García, Erica C/van Putte, Florimon, La mejor palabra es la que no se habla, in: Pensado, Carmen (ed.), El complemento directo preposicional, Madrid, Visor Libros, 1995, 113-132.

García García, Marco, Differential object marking with inanimate objects, in: Kaiser, Georg A./Leonetti, Manuel (edd.), Proceedings of the workshop «Definiteness, specificity and animacy in Ibero-Romance languages», Konstanz, Fachbereich Sprachwissenschaft der Universität Konstanz, 2007, 63-84.

García García, Marco, Differentielle Objektmarkierung bei unbelebten Objekten im Spanischen, Berlin/Boston, De Gruyter, 2014.

García García, Marco, Nominal and verbal parameters in the diachrony of differential object marking in Spanish, in: Seržant, Ilja A./Witzlack-Makarevich, Alena (edd.), Diachrony of differential argument marking, Berlin, Language Science Press, 2018, 209-242.

Garey, Howard B., Verbal aspect in French, Language 33:2 (1957), 91-110.

Givón, Talmy, Topic, pronoun, and grammatical agreement, in: Li, Charles (ed.), Subject and topic, New York, Academic Press, 1976, 149-188.

Givón, Talmy, Definiteness and referentiality, in: Greenberg, Joseph/Ferguson, Charles/ Moravcsik, Edith (edd.), Definiteness and referentiality, Stanford, CA, Stanford University Press, 1978, 291-330.

Givón, Talmy, Direct object and dative shifting. Semantic and pragmatic case, in: Plank, Frans (ed.), Objects. Towards a theory of grammatical relations, New York, Academic Press, 1984, 151-182.

Gruber, Jeffrey Steven, Studies in lexical relations, Cambridge, MA, Massachusetts Institute of Technology, 1965.

Gutiérrez-Rexach, Javier, Tener y el efecto de definitud, Cuadernos de lingüística VII (2000), 19-37.

Hale, Ken/Keyser, Samuel Jay, The syntactic character of argument structure, in: Roca, Iggy M. (ed.), Thematic structure. Its role in grammar, Foris, Dordrecht, 1992, 107-144.

Hawkins, John, Definiteness and indefiniteness. A study in reference and grammaticality prediction, London, Croom Helm, 1978.

Hawkinson, Annie K/Hyman, Larry M, Hierarchies of natural topic in Shona, Studies in African linguistics 5:2 (1974), 147.

Hay, Jennifer/Kennedy, Christopher/Levin, Beth, Scalar structure underlies telicity in «degree achievements», in: Proceedings of the 9th semantics and linguistic theory conference, Ithaca, Cornell University, 1999, 127-144.

Heim, Irene, The semantics of definite and indefinite noun phrases, Doctoral thesis, University of Massachusetts, 1982.

von Heusinger, Klaus, Salience and definiteness, The Prague bulletin of mathematical linguistics 67 (1997), 5-23.

von Heusinger, Klaus, Specificity and definiteness in sentence and discourse structure, Journal of semantics 19:3 (2002), 245-274.

von Heusinger, Klaus, Verbal semantics and the diachronic development of DOM in Spanish, Probus 20 (2008), 1-31. 
von Heusinger, Klaus, The diachronic development of differential object marking in Spanish ditransitive constructions, in: Seržant, Ilja A./Witzlack-Makarevich, Alena (edd.), Diachrony of differential argument marking, Berlin, Language Science Press, 2018, 315-344.

von Heusinger, Klaus, Specificity, in: Portner, Paul/von Heusinger, Klaus/Maienborn, Claudia (edd.), Semantics. Noun phrases and verb phrases, Berlin/Boston, De Gruyter Mouton, 2019, 70-111.

von Heusinger, Klaus/Kaiser, Georg A., The evolution of differential object marking in Spanish, in: von Heusinger, Klaus (ed.), Proceedings of the workshop «Specificity and the evolution/ emergence of nominal determination systems in Romance», Konstanz, Fachbereich Sprachwissenschaft der Universität Konstanz, 2005, 33-69.

von Heusinger, Klaus/Kaiser, Georg A., Differential object marking and the lexical semantics of verbs in Spanish, in: Kaiser, Georg A./Leonetti, Manuel (edd.), Proceedings of the workshop «Definiteness, specificity and animacy in Ibero-Romance Languages», Konstanz, Fachbereich Sprachwissenschaft der Universität Konstanz, 2007, 85-110.

von Heusinger, Klaus/Kaiser, Georg A., Affectedness and differential object marking in Spanish, Morphology 21:3-4 (2011), 593-617.

von Heusinger, Klaus/Kornfilt, Jaklin, The case of the direct object in Turkish. Semantics, syntax and morphology, Turkic languages 9 (2005), 3-44.

Himmelmann, Nikolaus P./Primus, Beatrice, Prominence beyond prosody. A first approximation, in: Dominicis, Amadeo de (ed.), pS-prominenceS: prominences in linguistics. Proceedings of the international conference, Viterbo, Disucom Press, 2015, 38-58.

Hoff, Mark R., Are Argentines «a»-blind? Acceptability of «a»-marked inanimate direct objects, in: MacDonald, Jonathan E. (ed.), Contemporary trends in Hispanic and Lusophone linguistics. Selected papers from the Hispanic linguistic symposium 2015, Amsterdam/ Philadelphia, John Benjamins, 2018, 121-142.

Hoff, Mark R./Díaz-Campos, Manuel, Conciencia y actitudes. El caso de la «a» acusativa en el español argentino, Signo y seña 28 (2015), 89-110.

de Hoop, Helen, Against affectedness, in: Lestrade, Sander/de Swart, Peter/Hogeweg, Lotte (edd.), Addenda: artikelen voor Ad Foolen, Nijmegen, Radboud University, 2015, 169-176.

de Hoop, Helen/Malchukov, Andrej L., Case-marking strategies, Linguistic inquiry 39:4 (2008), 565-587.

de Hoop, Helen/Narasimhan, Bhuvana, Differential case-marking in Hindi, in: Amberber, Megistu/Hoop, Helen de (edd.), Competition and variation in natural languages. The case for case, Amsterdam/San Diego/Oxford/London, Elsevier Science, 2005, 321-345.

Hopper, Paul J./Thompson, Sandra A., Transitivity in grammar and discourse, Language 56:2 (1980), 251-299.

lemmolo, Giorgio, Topicality and differential object marking. Evidence from Romance and beyond, Studies in language 34:2 (2010), 239-272.

Jackendoff, Ray, Semantic interpretation in generative grammar, Cambridge, MA, Mit Press, 1972.

Jackendoff, Ray, Semantic structures, Cambridge, MA, MIT Press, 1990.

Jackendoff, Ray, The proper treatment of measuring out, telicity, and perhaps even quantification in English, Natural language \& linguistic theory 14:2 (1996), 305-354.

Jaeggli, Osvaldo A., Passive, Linguistic inquiry 17:4(1986), 587-622.

Kabatek, Johannes, Un nuevo capítulo en la lingüística histórica iberorrománica. El trabajo crítico con los corpus, in: Kabatek, Johannes (ed.), Lingüística de corpus y lingüística histórica iberorrománica, Berlin/Boston, De Gruyter, 2016, 1-17. 
Kagan, Olga, Differential object marking, in: Kagan, Olga (ed.), The semantics of case, Cambridge, Cambridge University Press, 2020, 147-188.

Kamp, Hans, $A$ theory of truth and semantic representation, in: Portner, Paul/Partee, Barbara (edd.), Formal semantics. The essential readings, Oxford, Blackwell Publishers, 1981, 189-222.

Karttunen, Lauri, Discourse referents, in: McCawley, James D. (ed.), Notes from the linguistic underground, New York, Academic Press, 1976, 363-385.

Keenan, Edward L, Towards a universal definition of «subject», in: Li, Charles (ed.), Subject and topic, New York, Academic Press, 1975, 304-333.

Kiparsky, Paul, Partitive case and aspect, in: Butt, Miriam/Geuder, Wilhelm (edd.), The projection of arguments. Lexical and compositional factors, Stanford, CSLI Publications, 1998.

Kittilä, Seppo, On the encoding of transitivity-related features on the indirect object, Functions of language 14:1 (2007), 149-164.

Kliffer, Michael D., El «a» personal, la kínesis y la individuación, in: Pensado Ruiz, Carmen (ed.), El complemento directo preposicional, Madrid, Visor Libros, 1995, 93-111.

Krause, Elif/von Heusinger, Klaus, Gradient effects of animacy on differential object marking in Turkish, Open linguistics 5:1 (2019), 171-190.

Krifka, Manfred, Mass terms, plural telicity. Towards a semantics of quantity, in: Groenendijk, Jeroen/Stokhof, Martin/Veltman, Frank (edd.), Proceedings of the sixth Amsterdam colloquium on formal methods in the study of language, Amsterdam, Universiteit van Amsterdam, 1988, 153-173.

Krifka, Manfred, Nominal reference, temporal constitution and quantification in event semantics, in: Bartsch, Renate/van Benthem, Johan/van Emde Boas, Peter (edd.), Semantics and contextual expression, Dordrecht, Foris, 1989, 115.

Krifka, Manfred, The origins of telicity, in: Rothstein, Susan (ed.), Events and grammar, Amsterdam, Kluwer Academic Publishers, 1998, 197-235.

Laca, Brenda, Sobre el uso del acusativo preposicional en español, in: Pensado Ruiz, Carmen (ed.), El complemento directo preposicional, Madrid, Visor Libros, 1995, 61-92.

Laca, Brenda, El objeto directo preposicional, in: Company Company, Concepción (ed.), Sintaxis histórica de la lengua española, vol. 1, México, UNAM-Fondo de Cultura Económica, 2006, 423-478.

Lakoff, George, Linguistic Gestalts, in: Beach, Woodford A./Fox, Samuel E./Philosoph, Shulamith (edd.), Papers from the thirteenth regional meeting of the Chicago Linguistics Society, Chicago, Chicago Linguistic Society, 1977, 236-287.

Lakoff, George, Women, fire, and dangerous things. What categories reveal about the mind, Chicago, The University of Chicago Press, 1987.

Lambert, Silke, Beyond recipients. Towards a typology of dative uses, State University of New York at Buffalo, 2010.

Lambrecht, Knud, Information structure and sentence form. Topic, focus, and the mental representations of discourse referents, Cambridge, Cambridge University Press, 1994.

Lapesa, Rafael, Historia de la lengua española, Madrid, Gredos, 1981.

Lazard, Gilbert, What is an object in a crosslinguistic perspective?, in: Fiorentino, Giuliana (ed.), Romance objects. Transitivity in Romance languages, Berlin/New York, De Gruyter Mouton, 2003, 1-16.

Lazard, Gilbert, Le marquage différentiel de l'objet, in: Haspelmath, Martin, et al. (edd.), Language typology and language universals, vol. 2, Berlin/New York, De Gruyter Mouton, 2008, 873-885. 
Lenz, Rodolfo, La oración y sus partes. Estudios de gramática general y castellana, Madrid, Publicaciones de la revista de filología española, 1920.

Leonetti, Manuel, Specificity and differential object marking in Spanish, Catalan journal of linguistics 3:1 (2004), 75-114.

Leonetti, Manuel, Indefiniteness and specificity, in: Hualde, José Ignacio/Olarrea, Antxon/ O'Rourke, Erin (edd.), The handbook of Hispanic linguistics, Malden, Wiley/Blackwell, 2012, 285-306.

Leonetti, Manuel, Gramática y pragmática en el orden de palabras, Linred: lingüística en la red 12 (2014), 1-25.

Leonetti, Manuel/Escandell-Vidal, M. Victoria, Fronting and verum focus in Spanish, in: Dufter, Andreas/Jacob, Daniel (edd.), Focus and background in Romance languages, Amsterdam, John Benjamins, 2009, 155-204.

Lewis, David, Scorekeeping in a language game, in: Bäuerle, Rainer/Egli, Urs/Stechow, Arnim von (edd.), Semantics from different points of view, Berlin/Heidelberg, Springer, 1979, 172-187.

Löfstedt, Bengt, Studien über die Sprache der Langobardischen Gesetze, Stockholm, Almqvist \& Wiksell, 1961.

López, Luis, Indefinite objects. Scrambling, choice functions, and differential marking, MIT Press, 2012.

López, Luis, (In)definiteness, specificity, and differential object marking, in: Fischer, Susann/ Gabriel, Christoph (edd.), Manual of grammatical interfaces in Romance, Berlin/Boston, De Gruyter, 2016, 241-266.

Malchukov, Andrej, Animacy and asymmetries in differential case marking, Lingua 118:2 (2008), 203-221.

Marín, Rafael, Una propuesta para el tratamiento de la información aspectual en HPSG, Procesamiento del lenguaje natural 24 (1999).

Melis, Chantal, El objeto directo personal en el «Cantar del Mio Cid». Estudio sintácticopragmático, in: Pensado, Carmen (ed.), El complemento directo preposicional, Madrid, Visor Libros, 1995, 133-164.

Melis, Chantal, Spanish indexing DOM, topicality, and the case hierarchy, in: Seržant, Ilja A./ Witzlack-Makarevich, Alena (edd.), Diachrony of differential argument marking, Berlin, Language Science Press, 2018, 97-128.

Meyer-Lübke, Wilhelm, Grammatik der romanischen Sprachen. Romanische Syntax, Hildesheim, Georg Olms Verlag, 1899.

Miguel, Elena de, El aspecto léxico, in: Ignacio, Bosque/Demonte, Violeta (edd.), Gramática descriptiva de la lengua española, vol. 2: Las construcciones sintácticas fundamentales. Relaciones temporales, aspectuales y modales, Madrid, Espasa Calpe, 1999, 2977-3060.

Miller, Jordan/Currie, Sinéad/O'Carroll, Ronan E., «What if I'm not dead?». Myth-busting and organ donation, British journal of health psychology 24:1 (2019), 141-158.

Mithun, Marianne, The languages of native North America, Cambridge, Cambridge University Press, 1999.

Mohanan, Tara, Argument structure in Hindi, Center for the Study of Language (CSLI), 1994.

Montrul, Silvina, La marcación diferencial del objeto directo en el español de Argentina. Un estudio experimental, in: Colantoni, Laura/Rodríguez Louro, Celeste (edd.), Perspectivas teóricas y experimentales sobre el español de la Argentina, Madrid/Frankfurt am Main, Iberoamericana/Vervuert, 2013, 207-228. 
Moros, Luis, et al., Observaciones sobre el uso de la preposición «a» en el objeto directo. Un estudio sobre el español de Mérida, Letras 59 (1999), 89-120.

Müller, Bodo, Das morphemmarkierte Satzobjekt der romanischen Sprachen (Der sogenannte präpositionale Akkusativ), Zeitschrift für romanische Philologie 87:5-6 (1971), 477-519.

Næss, Åshild, What markedness marks. The markedness problem with direct objects, Lingua 114:9-10 (2004), 1186-1212.

Næss, Åshild, Prototypical transitivity, Amsterdam, John Benjamins, 2007.

Neale, Stephen, Descriptions, Cambridge, MA, MIT Press, 1990.

Nebrija, Antonio de, Gramática castellana, manuscrito digitalizado de la BNE, 1492, 39, http://bdh-rd.bne.es/viewer.vm?id=0000174208\&page=1 [último acceso: 17/09/2021].

Niculescu, Alexandru, Asupra obiectului direct prepozițional în limbile romanice, Studii și cercetări lingvistice 2 (1959), 185-204.

Nikolaeva, Irina, Secondary topic as a relation in information structure, Linguistics 39:1 (2001), 1-49.

Octavio de Toledo y Huerta, Álvaro Sebastián, Un rasgo sintáctico del primer español moderno (ca. 1675-1825). Las relaciones interoracionales con «ínterin (que)», in: Fernández Alcaide, Marta/López Serena, Araceli (edd.), Cuatrocientos años de la lengua del «Quijote». Estudios de historiografía e historia de la lengua española. Actas del V congreso nacional de la Asociación de Jóvenes Investigadores de Historiografía e Historia de la Lengua Española, Sevilla, Universidad de Sevilla, 2005, 421-442.

Ordóñez, Francisco/Treviño, Esthela, Agreement and DOM with impersonal «se». A comparative study of Mexican and Peninsular Spanish, in: Kato, Mary/Ordóñez, Francisco (edd.), The morphosyntax of Portuguese and Spanish in Latin America, Oxford, Oxford University Press, 2016, 236-258.

Ormazábal, Javier/Romero, Juan, The object agreement constraint, Natural language \& linguistic theory 25:2 (2007), 315-347.

Ormazábal, Javier/Romero, Juan, Prolegomena to the study of object relations, Lingvisticæ investigationes 42:1 (2019), 102-131.

Ortiz Ciscomani, Rosa María, Construcciones bitransitivas en la historia del español, México D.F., UNAM, Instituto de Investigaciones Filológicas, 2011.

Partee, Barbara, Weak NPs in «have»-sentences, in: Partee, Barbara (ed.), Compositionality in formal semantics, Oxford, Blackwell Publishing, 1999, 282-291.

Pensado, Carmen, El complemento directo preposicional. Estado de la cuestión y bibliografía comentada, in: Pensado, Carmen (ed.), El complemento directo preposicional, Madrid, Visor Libros, 1995, 11-60 (=1995a).

Pensado, Carmen, La creación del complemento directo preposicional y la flexión de los pronombres personales en la lenguas románicas, in: Pensado, Carmen (ed.), El complemento directo preposicional, Madrid, Visor Libros, 1995, 179-233 (= 1995b).

Pinkster, Harm, Sintaxis y semántica del latín, Madrid, Ediciones Clásicas, 1995.

Pottier, Bernard, Sur la nature du cas et de la préposition, in: István, Frank (ed.), Mélanges de linguistique et de littérature romanes à la mémoire d'István Frank, offerts par ses anciens maîtres, ses amis et ses collègues de France et de l'étranger, Saarbrücken, Universität des Saarlandes, 1957, 546-551.

Pottier, Bernard, L'emploi de la préposition «a» devant l'objet en espagnol, Bulletin de la Société de Linguistique 1 (1968), 83-95.

Primus, Beatrice, Cases and thematic roles, Tübingen, Max Niemeyer Verlag, 1999. 
Primus, Beatrice, Mismatches in semantic-role hierarchies and the dimensions of role semantics, in: Bornkessel, Ina, et al. (edd.), Semantic role universals and argument linking, Berlin, De Gruyter Mouton, 2006, 53-87.

Primus, Beatrice, Animacy, generalized semantic roles, and differential object marking, in: Lamers, Monique/de Swart, Peter (edd.), Case, word order and prominence, Heidelberg, Springer, 2012, 65-90.

Quine, Willard van Orman, Quantifiers and propositional attitudes, The journal of philosophy 53:5 (1956), 177-187.

Rappaport-Hovav, Malka/Levin, Beth, An event structure account of English resultatives, Language 77:4 (2001), 766-797.

Roberts, Ian, The representation of implicit and dethematized subjects, Berlin, De Gruyter Mouton, 1987.

Rodríguez-Mondoñedo, Miguel, The syntax of objects. Agree and differential object marking, Doctoral thesis, University of Connecticut, 2007, https://opencommons.uconn.edu/ dissertations/AAl3276641 [último acceso: 17/09/2021].

Roegiest, Eugeen, A propos de l'accusatif prépositionnel dans quelques langues romanes, Vox romanica 38 (1979), 38-55.

Roegiest, Eugeen, La tipología sintáctica del objeto transitivo en español, Verba. Anuario galego de filoloxía 17 (1990), 239-248.

Rohlfs, Gerhard, Autour de l'accusatif prépositionnel dans les langues romanes. Concordances et discordances, Revue de linguistique romane 35 (1971), 312-334.

Romero Heredero, Diego, Telicity and differential object marking in the history of Spanish, in: Kabatek, Johannes/Obrist, Philipp/Wall, Albert (edd.), Differential object marking in Romance. The third wave, Berlin/Boston, De Gruyter, 2021, 315-338.

Rosch, Eleanor, Principles of categorization, in: Rosch, Eleanor/Lloyd, Barbara B. (edd.), Cognition and categorization, Hillsdale, New Jersey, Lawrence Erlbaum Associates Publishers, 1978, 2-48.

Russell, Bertrand, On denoting, Mind 14:56 (1905), 479-493.

Sánchez López, Cristina, The possessive dative and the syntax of affected arguments, Cuadernos de lingüística del IUI Ortega y Gasset 14 (2007), 153-173.

Schütze, Carson T./Sprouse, Jon, Judgment data, in: Podesva, Robert J./Sharma, Devyani (edd.), Research methods in linguistics, Cambridge, Cambridge University Press Cambridge, 2014, 27-50.

Seržant, Ilja A./Witzlack-Makarevich, Alena, Diachrony of differential argument marking, Berlin, Language Science Press, 2018.

Silverstein, Michael, Hierarchy of features and ergativity, in: Dixon, Robert M.W. (ed.), Grammatical categories in Australian languages, Canberra, Australian Institute of Aboriginal Studies, 1976, 163-232.

Sinnemäki, Kaius, A typological perspective on differential object marking, Linguistics 52:2 (2014), 281-313.

Smith, Carlota S., The parameter of aspect, Dordrecht, Kluwer Academic Publishers, 1991.

Spitzer, Leo, Rum. «P(r)e», Span. «a» vor persönlichem Akkusativobjekt, Zeitschrift für romanische Philologie 48 (1928), 423-432.

Steen, Gerard J./Reijnierse, W. Gudrun/Burgers, Christian, When do natural language metaphors influence reasoning? A follow-up study to Thibodeau and Boroditsky, PloS one 9: 12 (2014), DOI: https://doi.org/10.1371/journal.pone.0113536 
de Swart, Peter, The case mirror, unpublished Master's thesis, Nijmegen, Radboud University Nijmegen, 2003.

de Swart, Peter, Cross-linguistic variation in object marking, Utrecht, Radboud University Nijmegen, 2007.

de Swart, Peter/de Hoop, Helen, Semantic aspects of differential object marking, in:

Puig-Waldmüller, Estela (ed.), Proceedings of «Sinn und Bedeutung», Barcelona, Universitat Pompeu Fabra, 2007, 598-611.

de Swart, Peter/de Hoop, Helen, Shifting animacy, Theoretical linguistics 44: 1-2 (2018), 1-23.

de Swart, Peter/Lamers, Monique/Lestrade, Sander, Animacy, argument structure, and argument encoding, Lingua 118:2 (2008), 131-140.

Talmy, Leonard, Semantic causative types, in: Shibatani, Masayoshi (ed.), Syntax and semantics, vol. 6: The grammar of causative constructions, New York, Academic Press, 1976, 43-116.

Talmy, Leonard, Force dynamics in language and cognition, Cognitive science 12:1 (1988), 49-100.

Talmy, Leonard, Toward a cognitive semantics, vol. 1: Concept structuring systems, Cambridge, MIT Press, 2000.

Tenny, Carol Lee, Grammaticalizing aspect and affectedness, Doctoral thesis, Cambridge, MA, Massachusetts Institute of Technology, 1987.

Tenny, Carol Lee, Aspectual roles and the syntax-semantics interface, Dordrecht, Kluwer Academic, 1994.

Testelec, Yakov G., On two parameters of transitivity in: Kulikov, Leonid/Vater, Heinz (edd.), Typology of verbal categories, Tübingen, Max Niemeyer Verlag, 1998, 29-45.

Tippets, Ian Robert, Differential object marking in Spanish. A quantitative variationist study, Ohio, Ohio State University, 2010.

Tippets, Ian Robert, Differential object marking. Quantitative evidence for underlying hierarchical constraints across Spanish dialects, in: Ortiz-López, Luis A. (ed.), Selected proceedings of the 13th Hispanic linguistics symposium, Somerville, MA, Cascadilla Proceedings Project, 2011, 107-117.

Torrego, Esther, The dependencies of objects, Cambridge, MA, MIT Press, 1998.

Torrego, Esther, El complemento directo preposicional, in: Bosque, Ignacio/Demonte, Violeta (edd.), Gramatica descriptiva de la lengua española, vol. 2: Las construcciones sintácticas fundamentales. Relaciones temporales, aspectuales y modales, Madrid, Espasa Calpe, 1999, 1779-1805.

Torrego, Esther, Las dependencias de los objetos, Madrid, Antonio Machado Libros, 2002. Travis, Lisa de Mena, Inner aspect. The articulation of VP, Dordrecht, Springer, 2010.

Tsunoda, Tasaku, Remarks on transitivity, Journal of linguistics 21:2 (1985), 385-396.

Tsunoda, Tasaku, Transitivity and intransitivity, Journal of Asian and African studies 57 (1999), 1-9.

Valdés, Juan de, El diálogo de la lengua, manuscrito digitalizado de la BNE, 1535, 167, http://bdh-rd.bne.es/viewer.vm?id=0000048928 [último acceso: 17/09/2021].

Van Valin, Robert D./LaPolla, Randy J., Syntax. Structure, meaning, and function, Cambridge, Cambridge University Press, 1997.

Vendler, Zeno, Verbs and times, Philosophical review 66:2 (1957), 143-160. 
Verkuyl, Hendrik Jacob, On the compositional nature of the aspects, Dordrecht, D. Reidel Publishing Company, 1972.

Weissenrieder, Maureen, Exceptional uses of the accusative «a», Hispania 68:2 (1985), 393-398.

Yamamoto, Mutsumi, Animacy and reference. A cognitive approach to corpus linguistics, Amsterdam, John Benjamins Publishing, 1999. 
